\title{
Dabigatran-induced oesophagitis improved by switching medication to apixaban
}

\author{
Kosuke Ishizuka (1) , ${ }^{1}$ Daiki Yokokawa 다, ${ }^{1}$ Takahiro Mori, ${ }^{2}$ Masatomi Ikusaka ${ }^{1}$
}

'Department of General Medicine, Chiba University Hospital, Chiba, Japan 2Department of General Internal Medicine, Eastern Chiba Medical Center, Togane, Japan

\section{Correspondence to} Kosuke Ishizuka; e103007c@yokohama-cu.ac.jp

Accepted 8 August 2021

Check for updates

(c) BMJ Publishing Group Limited 2021. No commercial re-use. See rights and permissions. Published by BMJ.

\begin{tabular}{|l|}
\hline To cite: Ishizuka K, \\
Yokokawa D, Mori T, \\
et al. BMJ Case Rep \\
2021;14:e245443. \\
doi:10.1136/bcr-2021- \\
245443 \\
\hline
\end{tabular}

\section{DESCRIPTION}

An 85-year-old man presented to our clinic with chest discomfort for a month while swallowing solids. His symptoms did not change with posture. He had experienced no change in body weight. His medical history revealed hypertension, type 2 diabetes mellitus and paroxysmal atrial fibrillation, for which he had been prescribed oral doses of $80 \mathrm{mg} /$ day of telmisartan, $1000 \mathrm{mg} /$ day of metformin, $2.5 \mathrm{mg} /$ day of bisoprolol, $100 \mathrm{mg} /$ day of diltiazem hydrochloride and $220 \mathrm{mg} /$ day of dabigatran etexilate. His vital signs were unremarkable. Laboratory tests showed no abnormalities. One week later, an oesophagogastroduodenoscopy showed erosions in the lower oesophagus (figure 1). The biopsy of the lesions revealed no remarkable findings other than mild inflammatory cell infiltration into the epithelium.

Because drugs could cause oesophagitis, we further investigated his medication history thoroughly. It revealed that the direct oral anticoagulant (DOAC) had been switched from apixaban to dabigatran 2 months before when the doctor in charge of management of paroxysmal atrial fibrillation changed from a cardiologist at a general hospital to his family doctor. He took dabigatran with a large amount of water as his family doctor instructed. However, he used to lie down immediately after consuming the medication. Therefore, we considered dabigatran-induced oesophagitis (DIE). His oral medication was reverted to apixaban, and his condition improved in a few days.

Various drugs have been shown to cause oesophagitis, including non-steroidal antiinflammatory drugs, quinidine, doxycycline, tetracycline, clindamycin, ideocyclin, oxytetral ferrous sulfate, ascorbic acid, alprenolol chloride, theophylline, mycophenolate mofetil, warfarin, cyproterone acetate, ethinylestradiol, rifampin, cefotiam hydrochloride, phenytoin and dabigatran. ${ }^{1}$ Toya et al reported that DIE occurred in $21 \%$ of patients who took dabiga$\operatorname{tran}^{1}$; furthermore, in the reviewed literature, no cases of oesophagitis induced by DOACs other than dabigatran have been reported. ${ }^{1}$ Dabigatran is prescribed as a relatively large capsule (18-19 mm in length, 280-390 mg in weight), which can easily get lodged in the oesophagus. ${ }^{2}$ It is reported that the size and weight of the capsule affect the oesophageal transit time, and capsules are more likely to adhere to the oesophageal mucosa compared with tablets. ${ }^{2} 3$ Therefore, dabigatran has a tendency to get lodged in

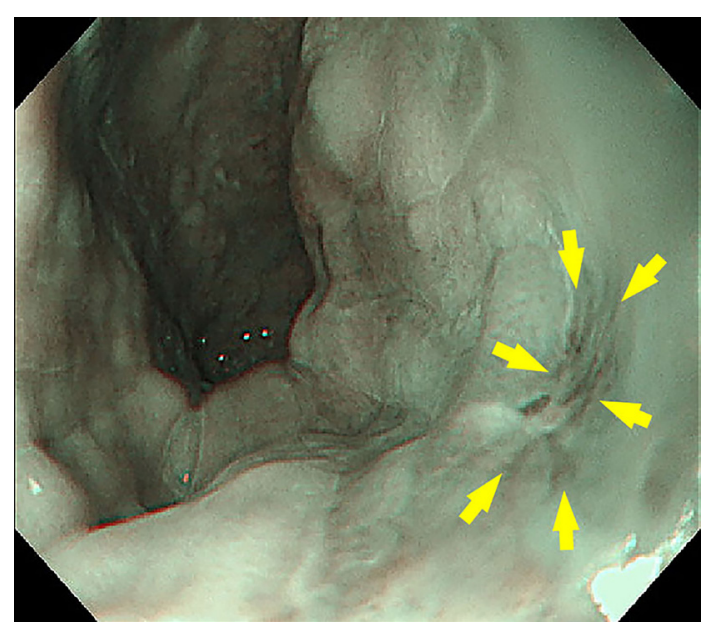

Figure 1 Oesophagogastroduodenoscopy showed erosions in the lower oesophagus.

the oesophagus. ${ }^{2}$ Dabigatran is the only DOAC containing the eluting tartaric acid core, which can cause oesophageal injury. ${ }^{2}$ Because dabigatran can dissolve in a strongly acidic environment, it has tartaric acid as the core, which is coated with dabigatran etexilate. ${ }^{2}$ The $\mathrm{pH}$ of tartaric acid is 2.4; a significantly acidic environment is created. ${ }^{2}$ Instructing patients to take dabigatran orally with a large amount of water and to maintain an upright position for a while after taking it have been reported as effective ways to prevent dabigatran from lodging in the oesophagus. ${ }^{2}$ For patients who cannot continue taking dabigatran due to side effects, switching

\section{Learning points}

- Oesophagitis occurs in $21 \%$ of patients who took dabigatran; furthermore, in the reviewed literature, no cases of oesophagitis induced by direct oral anticoagulant (DOACs) other than dabigatran have been reported.

- Dabigatran is the only DOAC containing the eluting tartaric acid core that can cause oesophageal injury. Because dabigatran can dissolve in a strongly acidic environment, it has tartaric acid as the core, which is coated with dabigatran etexilate.

- Patients who cannot continue taking dabigatran due to side effects such as oesophagitis, switching to another DOAC may be effective to improve gastrointestinal symptoms. 
to another DOAC may be an effective way to improve gastrointestinal symptoms.

Contributors $\mathrm{Kl}$ identified the significance of the case and wrote the manuscript, and DY, TM and MI revised it. All authors approved the final version of the manuscript.

Funding The authors have not declared a specific grant for this research from any funding agency in the public, commercial or not-for-profit sectors.

Competing interests None declared.

Patient consent for publication Obtained.

Provenance and peer review Not commissioned; externally peer reviewed.

\section{ORCID iDs}

Kosuke Ishizuka http://orcid.org/0000-0003-4313-6592

Daiki Yokokawa http://orcid.org/0000-0003-0944-8664

\section{REFERENCES}

1 Toya Y, Nakamura S, Tomita K, et al. Dabigatran-induced esophagitis: the prevalence and endoscopic characteristics. J Gastroenterol Hepatol 2016;31:610-4.

2 Tajima H, Narasaka T, Akutsu D, et al. The risks of exfoliative esophagitis in patients with atrial fibrillation: a retrospective observational study. Medicine 2020:99:e21681.

3 Hey H, Jørgensen F, Sørensen K, et al. Oesophageal transit of six commonly used tablets and capsules. Br Med J 1982;285:1717-9.

Copyright 2021 BMJ Publishing Group. All rights reserved. For permission to reuse any of this content visit https://www.bmj.com/company/products-services/rights-and-licensing/permissions/

BMJ Case Report Fellows may re-use this article for personal use and teaching without any further permission.

Become a Fellow of BMJ Case Reports today and you can:

- Submit as many cases as you like

- Enjoy fast sympathetic peer review and rapid publication of accepted articles

- Access all the published articles

- Re-use any of the published material for personal use and teaching without further permission

\section{Customer Service}

If you have any further queries about your subscription, please contact our customer services team on +44 (0) 2071111105 or via email at support@bmj.com.

Visit casereports.bmj.com for more articles like this and to become a Fellow 